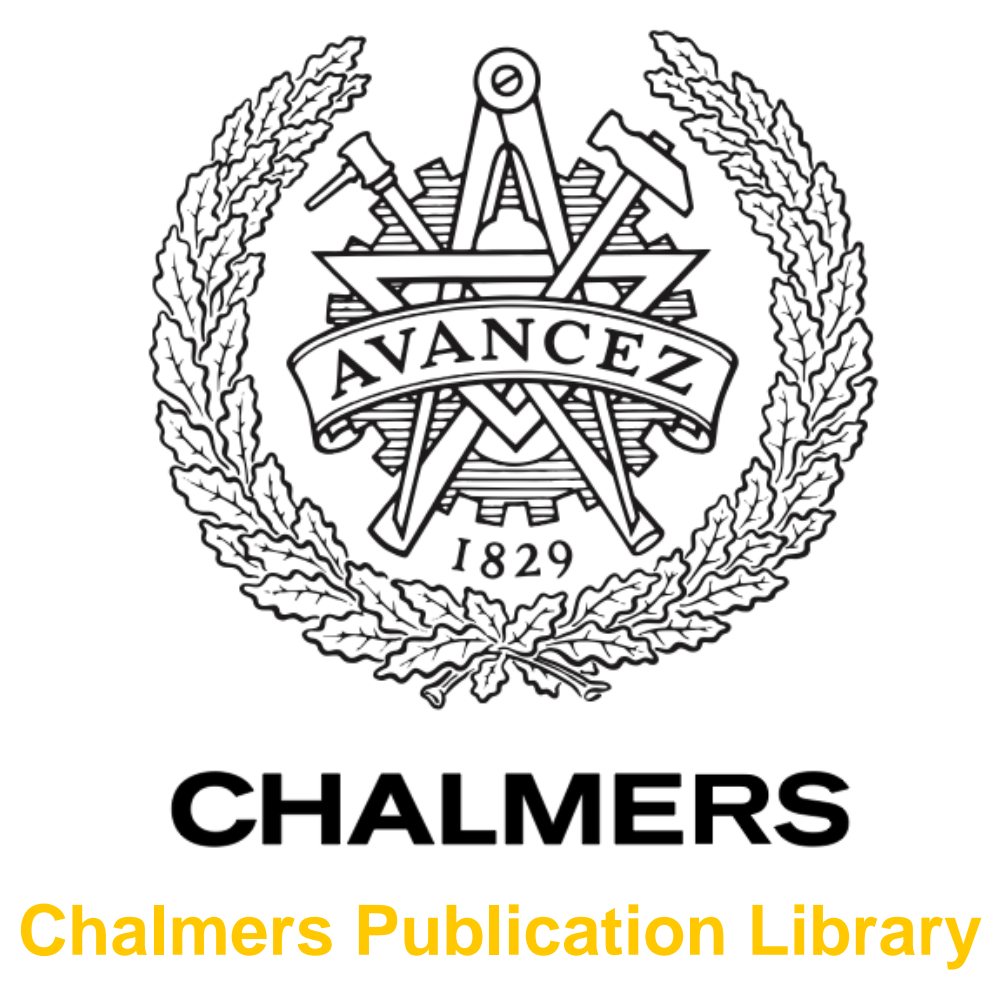

\title{
Formation of HNCO, HCN, and NH3 from the pyrolysis of bark and nitrogen- containing model compounds
}

This document has been downloaded from Chalmers Publication Library (CPL). It is the author's version of a work that was accepted for publication in:

Combustion and Flame (ISSN: 0010-2180)

Citation for the published paper:

Hansson, K. ; Samuelsson, J. ; Tullin, C. et al. (2004) "Formation of HNCO, HCN, and NH3 from the pyrolysis of bark and nitrogen-containing model compounds". Combustion and

Flame, vol. 137 pp. 265-277.

Downloaded from: http://publications.lib.chalmers.se/publication/239166

Notice: Changes introduced as a result of publishing processes such as copy-editing and formatting may not be reflected in this document. For a definitive version of this work, please refer to the published source. Please note that access to the published version might require a subscription. 


\title{
Formation of $\mathrm{HNCO}, \mathrm{HCN}$, and $\mathrm{NH}_{3}$ from the pyrolysis of bark and nitrogen-containing model compounds
}

\author{
Karl-Martin Hansson, ${ }^{\mathrm{a}, *}$ Jessica Samuelsson, ${ }^{\mathrm{b}}$ Claes Tullin, ${ }^{\mathrm{b}}$ \\ and Lars-Erik Åmand ${ }^{\text {a }}$ \\ a Department of Energy Conversion, Chalmers University of Technology, S-412 96 Göteborg, Sweden
b Swedish National Testing and Research Institute, Industrigatan 4, Box 857, S-501 15 Borås, Sweden
}

Received 13 May 2003; received in revised form 23 December 2003; accepted 9 January 2004

\begin{abstract}
Bark pellets have been pyrolyzed in a fluidized bed reactor at temperatures between 700 and $1000{ }^{\circ} \mathrm{C}$. Identified nitrogen-containing species were hydrogen cyanide $(\mathrm{HCN})$, ammonia $\left(\mathrm{NH}_{3}\right)$, and isocyanic acid $(\mathrm{HNCO})$. Quantification of $\mathrm{HCN}$ and to some extent of $\mathrm{NH}_{3}$ was unreliable at 700 and $800{ }^{\circ} \mathrm{C}$ due to low concentrations. $\mathrm{HNCO}$ could not be quantified with any accuracy at any temperature for bark, due to the low concentrations found. Since most of the nitrogen in biomass is bound in proteins, various protein-rich model compounds were pyrolyzed with the aim of finding features that are protein-specific, making conclusions regarding the model compounds applicable for biomass fuels in general. The model compounds used were a whey protein isolate, soya beans, yellow peas, and shea nut meal. The split between $\mathrm{HCN}$ and $\mathrm{NH}_{3}$ depends on the compound and temperature. It was found that the $\mathrm{HCN} / \mathrm{NH}_{3}$ ratio is very sensitive to temperature and increases with increasing temperature for all compounds, including bark. Comparing the ratio for the different compounds at a fixed temperature, the ratio was found to decrease with decreasing release of volatile nitrogen. The temperature dependence implies that heating rate and thereby particle size affect the split between $\mathrm{HCN}$ and $\mathrm{NH}_{3}$. For whey, soya beans, and yellow peas, $\mathrm{HNCO}$ was also quantified. It is suggested that most $\mathrm{HCN}$ and $\mathrm{HNCO}$ are produced from cracking of cyclic amides formed as primary pyrolysis products. The dependence of the $\mathrm{HNCO} / \mathrm{HCN}$ ratio on the compound is fairly small, but the temperature dependence of the ratio is substantial, decreasing with increasing temperature. The release of nitrogen-containing species does not seem to be greatly affected by the other constituents of the fuel, and proteins appear to be suitable model compounds for the nitrogen in biomass.
\end{abstract}

(C) 2004 The Combustion Institute. Published by Elsevier Inc. All rights reserved.

Keywords: Biomass; Pyrolysis; HNCO; HCN; Bark; Proteins

\section{Introduction}

Complete combustion is important in order to minimize emissions of harmful species such as carbon monoxide and various hydrocarbon compounds. However, to simultaneously minimize also the for-

\footnotetext{
* Corresponding author.

E-mail address: martinh@entek.chalmers.se (K.-M. Hansson).
}

mation of nitrogen compounds from the nitrogen in the fuel, it is important to apply air staging in such a way that the nitrogen compounds are reduced to molecular nitrogen in a reducing combustion zone before enough air is supplied to produce complete burnout. Undesirable nitrogen-containing combustion products are $\mathrm{NO}_{2}, \mathrm{NO}$, and $\mathrm{N}_{2} \mathrm{O}$. $\mathrm{NO}$ and $\mathrm{NO}_{2}$ cause acid rain and contribute to the formation of photochemical smog and ground-level ozone. $\mathrm{N}_{2} \mathrm{O}$ is a greenhouse gas and it also takes part in the destruction of the ozone layer in the stratosphere. 
Table 1

Literature data on $\mathrm{HCN}$ and $\mathrm{NH}_{3}$ yields from biomass pyrolysis

\begin{tabular}{llccrc}
\hline Biomass & Heating rate & $T_{\text {final }}\left({ }^{\circ} \mathrm{C}\right)$ & $\mathrm{NH}_{3}-\mathrm{N}(\%)$ & $\mathrm{HCN}-\mathrm{N}(\%)$ & Ref. \\
\hline Bagasse & Tube reactor & 800 & $\sim 12$ & $\sim 54$ & {$[22]$} \\
Rapeseed & Fluidized bed & $500-700$ & $\sim 11-27$ & n.a. & {$[32]$} \\
Wood bark (birch, fir, pine) & Entrained flow reactor & 800 & $4.5-5.5$ & $0.55-0.73$ & {$[8]$} \\
Wood bark (pine) & $10 \mathrm{~K} / \mathrm{min}$ & $810-930$ & $10-15$ & n.a. & {$[9]$} \\
\hline
\end{tabular}

n.a., not analyzed.

Advanced kinetic modeling of the gas-phase reactions is a useful tool to optimize the formation of molecular nitrogen from fuel nitrogen, while complete oxidation of the fuels is achieved. However, in order to be useful, the kinetic schemes need information on the primary volatile nitrogen species that result from pyrolysis. The question of whether the volatile nitrogen species are $\mathrm{NH}_{3}, \mathrm{HCN}$, or some other compounds is crucial for the results of the modeling. Gas combustion experiments, as well as kinetic modeling of combustible mixtures doped with $\mathrm{HCN}$, have revealed that $\mathrm{HCN}$ forms $\mathrm{NO}$ and $\mathrm{N}_{2} \mathrm{O}$ under combustion [1-3]. In mixtures doped with $\mathrm{NH}_{3}$, $\mathrm{NO}$ is formed, while $\mathrm{N}_{2} \mathrm{O}$ formation is negligible [1-3]. $\mathrm{HNCO}$ has not been as thoroughly investigated as $\mathrm{HCN}$ and $\mathrm{NH}_{3}$ but the formation of $\mathrm{N}_{2} \mathrm{O}$ is mainly a result of the reaction

$\mathrm{NCO}+\mathrm{NO} \rightarrow \mathrm{N}_{2} \mathrm{O}+\mathrm{CO}$.

HNCO can therefore be expected to be a precursor to $\mathrm{N}_{2} \mathrm{O}$ [1]. In fact, before $\mathrm{N}_{2} \mathrm{O}$ was recognized as a problem, urea was injected into hot combustion gases in order to reduce NO emissions (the SNCR process). However, this practice led to high emissions of $\mathrm{N}_{2} \mathrm{O}$ [4]; this is probably because $\mathrm{HNCO}$ is formed by the pyrolysis of urea [5].

Proteins have been found to be the main source of nitrogen in wood (see [6,7] for a review). However, during the past 10 years, the idea that most of the nitrogen in biomass is in the form of proteins has been seriously questioned. Instead it has been suggested that all nitrogen in biomass should be in heterocyclic aromatic structures [8-10], but as outlined in previous work [6,7], the evidence for nitrogen being in heterocyclic structures are not conclusive. In contrast, all available data support the view that proteins are the main source of nitrogen in wood and other biomass [6,7].

In previous studies, it has been suggested that the pyrolysis of proteins as model compounds would lead to increased insight regarding the formation of nitrogen-containing species from biomass [6,7]. These studies revealed that $\mathrm{HCN}, \mathrm{NH}_{3}$, and $\mathrm{HNCO}$ are the main pyrolysis products from proteins and that the amino acid composition of the protein greatly affects the distribution of nitrogen between the solid residue and the gas phase as well as the $\mathrm{HCN} / \mathrm{NH}_{3}$ selectivity. Since the amino acid composition of the proteins greatly affects the selectivity between volatile nitrogen and char nitrogen as well as the selectivity of the different volatile nitrogen-containing species, it is important to choose proteins that have amino acid compositions similar to those found in biomass when using proteins as model compounds [6]. The literature data on the formation of $\mathrm{HCN}$ and $\mathrm{NH}_{3}$ from biomass show great variations in yields (Table 1) and in $\mathrm{HCN} / \mathrm{NH}_{3}$ ratio. Due to the scatter in the results, it is not possible at present to predict the release of volatile nitrogen from biofuels. The differences can be an effect of different experimental conditions or inadequate gas analysis, but also of variations in the fuels. Different kinds of trees may have different amino acid compositions, and trees in the temperate zone show seasonal changes in protein concentrations and protein composition $[11,12]$. Because of these uncertainties it is important to investigate different proteins to find out which variations in pyrolysis products can be expected from biomass, and this is one of the objectives of this paper.

When biomass is pyrolyzed at low temperatures, most of the fuel nitrogen has been reported to be found in the char and tar (Table 2). However, nitrogen gas from air has been found to adsorb on chars derived from coal [13] and phenol formaldehyde resin [14] as well as on other carbon-rich solids such as molecular sieving carbon and activated carbon fiber [14]. The adsorbed nitrogen contributes to the total nitrogen content measured by instrumental analyzers based on combustion of the solid samples $[13,14]$. This is why this method can give overestimated nitrogen concentrations $[13,14]$. Nitrogen gas is expected to adsorb on biomass chars as well, and due to the low nitrogen concentrations in biomass such adsorbed nitrogen can contribute significantly to the analyzed concentrations. The low concentrations of nitrogen in biomass can also make quantification uncertain. The uncertainty in the analyzed amounts of nitrogen in fuel, char, and tar fractions is apparent from the fact that the reported nitrogen yields in char and tar fractions sometimes exceed $100 \%$ of the nitrogen in the original fuel (Table 2). Adsorbed nitrogen has probably contributed to the analyzed nitrogen in these cases. 
Table 2

Literature data on yields of nitrogen in char and tar (in some cases oil) fractions from biomass pyrolysis

\begin{tabular}{|c|c|c|c|c|c|}
\hline Biomass & Heating rate & $T_{\text {final }}\left({ }^{\circ} \mathrm{C}\right)$ & Char-N (\%) & Tar-N (\%) & Ref \\
\hline Bagasse & $12 \mathrm{~K} / \mathrm{min}$ & 500 & $\sim 50$ & n.a. & {$[17]$} \\
\hline Bagasse & $\sim 2.5 \mathrm{~K} / \mathrm{min}$ & 530 & $\sim 40$ & $\sim 45$ & {$[17]$} \\
\hline Coffee husk & & $500-900$ & $48-32$ & n.a. & {$[33]$} \\
\hline Cottonseed cake & $7 \mathrm{~K} / \mathrm{min}$ & 550 & n.a. & $\sim 135$ & {$[34]$} \\
\hline E. rigida & $7 \mathrm{~K} / \mathrm{min}$ & 500 & $\sim 19$ & $\sim 22$ & {$[35$} \\
\hline E. rigida & $7 \mathrm{~K} / \mathrm{min}$ & 500 & n.a. & $\sim 40$ & {$[36]$} \\
\hline Hazelnut shell & $7 \mathrm{~K} / \mathrm{min}$ & 500 & n.a. & $\sim 30$ & {$[36]$} \\
\hline Oil palm shell & Fluidized bed & 500 & n.a. & $\sim 70$ & {$[37]$} \\
\hline Olive husk & & 500 & $\sim 33$ & n.a. & {$[38]$} \\
\hline Olive bagasse & Isothermal & 500 & $\sim 50-100$ & n.a. & {$[39]$} \\
\hline \multirow[t]{2}{*}{ Olive waste } & & 800 & $40-50$ & n.a. & {$[40]$} \\
\hline & & 1000 & $25-30$ & & \\
\hline Rapeseed & $40 \mathrm{~K} / \mathrm{min}$ & 500 & n.a. & $\sim 50$ & {$[41]$} \\
\hline Rapeseed & $300 \mathrm{~K} / \mathrm{min}$ & 550 & $\sim 4$ & $\sim 37$ & {$[42]$} \\
\hline Rape (straw and stalk) & $30 \mathrm{~K} / \mathrm{min}$ & 650 & n.a. & $\sim 24$ & {$[43]$} \\
\hline Rape (straw and stalk) & $5 \mathrm{~K} / \mathrm{min}$ & $400-900$ & $75-53$ & n.a. & {$[44]$} \\
\hline Safflower seed & $5 \mathrm{~K} / \mathrm{min}$ & 500 & $\sim 28$ & $\sim 24$ & {$[45$} \\
\hline Sunflower (pressed) & $7 \mathrm{~K} / \mathrm{min}$ & 550 & n.a. & $\sim 55$ & {$[36]$} \\
\hline Sunflower (pressed) & $300 \mathrm{~K} / \mathrm{min}$ & 550 & $\sim 22$ & $\sim 45$ & {$[46]$} \\
\hline Sunflower (pressed) & $300 \mathrm{~K} / \mathrm{min}$ & 550 & n.a. & $\sim 51$ & {$[47]$} \\
\hline Sunflower (pressed) & Tubular reactor & 550 & $\sim 7$ & $\sim 35$ & {$[48]$} \\
\hline Wood (poplar) & Fluidized bed & 500 & $\sim 30$ & $>100$ & {$[49]$} \\
\hline Wood (bark mix) & Sealed batch reactor & 500 & n.a. & $\sim 25^{\mathrm{a}}$ & {$[50]$} \\
\hline Wood (bark mix) & & 500 & $\sim 30^{\mathrm{a}}$ & n.a. & {$[51]$} \\
\hline Wood (beech) & Fluidized bed & 800 & $\sim 32$ & n.a. & {$[52]$} \\
\hline Wood (birch) & Fluidized bed & 850 & $\sim 42$ & n.a. & {$[53]$} \\
\hline Wood (spruce) & Fluidized bed & 850 & $\sim 45$ & n.a. & {$[53$} \\
\hline Wood bark (pine) & $10 \mathrm{~K} / \mathrm{min}$ & $810-930$ & $\sim 60-80$ & n.a. & [9] \\
\hline
\end{tabular}

Many of the yields were calculated from char and tar yields and nitrogen concentrations in fuel, tar (or oil), and char. n.a., not analyzed.

a The nitrogen content in the fuel, $0.5 \%$ dry basis (2.5\% ash), was not given in Refs. [50] and [51].

Proteins that do not contain reactive side chains form cyclic dipeptides, 3,6-disubstituted-2,5-diketopiperazines (DKPs) [15]. DKPs belong to the group cyclic amides (Fig. 1). In a study on the mild pyrolysis of human hair, other cyclic amides known as 5-substituted-2,4-imidazolidinediones were suggested to be pyrolysis products from proteins [16]. From a study on the pyrolysis of bagasse, the cyclic amide 3-methyl-2,4-imidazolidinedione has been reported to be a pyrolysis product [17]. Pyrolysis of the polyamide nylon 6 at low temperatures produces the cyclic amide $\varepsilon$-caprolactam [18]. Proteins that contain amino acids with reactive side chains have been suggested to cross-link and form char [6,7].

Amides contain the functional group - NH-CO-. The linear amides (Fig. 2) urea [5], nylon 6,6 [19], and the proteins poly-L-leucine and poly-L-proline [6] all form HNCO under pyrolysis. Urea lacks the functional group -CHR-NH-, which nylon 6,6, as well as poly-L-leucine and poly-L-proline, has. Consequently, urea does not form $\mathrm{HCN}$ as the other linear amides do. All of the above-mentioned linear amides form ammonia under pyrolysis $[5,6,19]$. Urea has pri- mary amine groups, nylon 6,6 and poly-L-leucine mainly contain secondary amine groups (Fig. 2), and poly-L-proline mainly contains tertiary amine groups.

The cyclic amides 2-azetidinone [20], 2-pyridone, and 2,5-diketopiperazine [21] all form both HNCO and $\mathrm{HCN}$ under pyrolysis. It was suggested that all cyclic amides should decompose through similar reactions and that the selectivity between HNCO and $\mathrm{HCN}$ should have similar temperature dependencies for all cyclic amides [6]. The HNCO yield decreases and the $\mathrm{HCN}$ yield increases with increasing temperature for 2-azetidinone [20] as well as for 2-pyridone and 2,5-diketopiperazine [21]. Hence, the HNCO/ $\mathrm{HCN}$ ratio decreases with increasing temperature for all three cyclic amides.

The formation of light gases from proteins can be either directly from the polymer chain or from cracking of tar products. In either case, HNCO can be expected to be a pyrolysis product from proteins. Poly-L-leucine and poly-L-proline have previously been shown to produce $\mathrm{HNCO}$ as well as $\mathrm{HCN}$ and $\mathrm{NH}_{3}$ [6]. Since neither of these proteins has reactive side chains and since neither of them formed any char, 
<smiles>[R]C1NC(=O)C([R])N([2H])C1=O</smiles><smiles>CC(F)(F)CN1CCCCCC1=O</smiles>

5-substituted-2,4-imidazolidinediones<smiles>[R]C1NC(=O)N([2H])C1=O</smiles>

2-azetidinone<smiles>O=C1CCN1</smiles>

3-methyl-2,4-imidazolidinedione<smiles>CN1C(=O)CNC1=O</smiles>

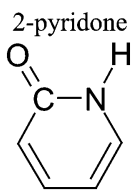

Fig. 1. Structures of cyclic amides. The letter $\mathrm{R}$ denotes side groups.

urea<smiles>NC=O</smiles>

poly-L-leucine

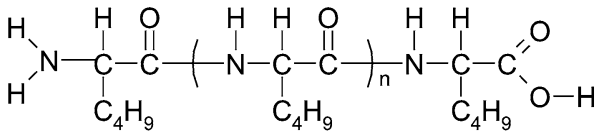

nylon 6,6

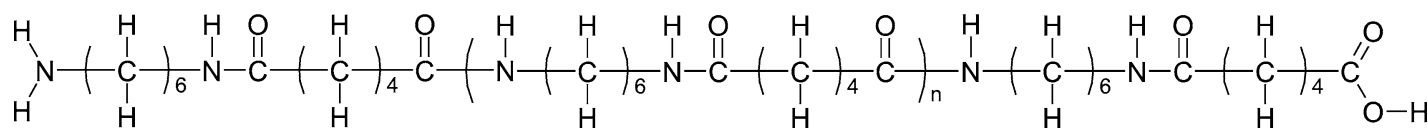

Fig. 2. Structures of linear amides.

it was suggested that the primary reaction for these two proteins was depolymerization to form DKP.

Little is known about the formation of $\mathrm{HCN}$ and $\mathrm{NH}_{3}$ from wood and other biomasses. The formation of HNCO had not been expected previously, which is reflected by the fact that the analysis method usually used $[8,9,22]$ to quantify $\mathrm{NH}_{3}$ (i.e., wet chemical analysis) converts $\mathrm{HNCO}$ into ammonia so that the measured concentrations of $\mathrm{NH}_{3}$ in fact are the sum of the concentrations of $\mathrm{NH}_{3}$ and $\mathrm{HNCO}$ [23].

The aim of this study was to investigate if $\mathrm{HNCO}$ is a pyrolysis product from wood and to investigate the selectivity between $\mathrm{HCN}$ and $\mathrm{NH}_{3}$ at different temperatures for bark and some model compounds. Since the low concentrations of nitrogen in wood lead to low concentrations of nitrogen-containing species in the gas phase, which complicates their analysis, bark was used due to its comparatively high nitrogen content. Furthermore, a whey protein isolate was found to have an amino acid composition approximately comparable to the amino acid compositions reported for Scots pine wood (Table 3). Therefore, this whey protein was used as a model compound for the nitrogen in wood. It is possible that reactions between proteins and the other constituents of biomass can occur in the condensed phase. Secondary reactions in the gas phase have also been suggested to have an impact on the distribution between $\mathrm{HCN}$ and $\mathrm{NH}_{3}$. The fuel's $\mathrm{O} / \mathrm{N}$ ratio has been suggested to be a measure of the fuel's tendency to take part in such secondary reactions [8]. That hypothesis was tested by including three more fuels in this study. The protein concentrations in these fuels are higher than in bark, but lower than for the whey protein isolate. Consequently, the five fuels have very different $\mathrm{O} / \mathrm{N}$ ratios, and the importance of this ratio on secondary reactions could be assessed.

\section{Experimental procedures}

\subsection{The fuel samples}

Five different biofuels have been pyrolyzed: bark, shea nut meal (i.e., the residue after oil extractionhere referred to as shea), yellow peas, soya beans, and whey protein. The elemental analysis of the fuels is listed in Table 4. The fuels' nitrogen content varies from 0.4 to $15.3 \mathrm{wt} \%$. The whey protein used in this study is an isolate called Lacprodan DI-9224. It contains less than $0.2 \%$ fat and lactose, respectively. The protein content is close to $90 \mathrm{wt} \%$. Five of the 
Table 3

Amino acid composition (molar \%) of the whey protein isolate used in this study and literature data on scots pine [54,55]

\begin{tabular}{lcccc}
\hline Amino acid & Whey protein & Scots pine $^{\mathrm{a}}[54]$ & Scots pine $^{\mathrm{b}}[54]$ & Scots pine [55] \\
\hline Alanine & 4.7 & 7.7 & 7.9 & 9.6 \\
Valine & 5.9 & 8.8 & 7.3 & 7.5 \\
Leucine & 10.2 & 7.2 & 6.1 & 7.9 \\
Isoleucine & 6.1 & 5.0 & 4.9 & 5.3 \\
Methionine & $\mathrm{c}$ & 1.4 & 2.0 & 1.7 \\
Proline & 1.8 & 3.0 & 6.1 & 5.8 \\
Phenylalanine & 5.8 & 4.7 & 4.1 & 3.7 \\
Tryptophan & 3.0 & 1.1 & 1.2 & n.a. \\
Glycine & 1.7 & 6.6 & 5.3 & 9.7 \\
Serine & 1.7 & 6.4 & 6.5 & 8.3 \\
Threonine & 5.0 & 6.4 & 7.3 & 7.5 \\
Tyrosine & 7.3 & 3.0 & 6.9 & 1.3 \\
Cysteine & 3.7 & 5.0 & 2.9 & n.a. \\
Aspartic acid & 2.4 & 9.4 & 7.8 & 9.6 \\
Glutamic acid & 11.0 & 9.9 & 7.8 & 9.9 \\
Lysine & 16.7 & 4.1 & 3.3 & 5.1 \\
Arginine & 9.2 & 3.3 & 2.4 & 4.2 \\
Histidine & 1.9 & 2.8 & 2.4 & 1.6 \\
\hline
\end{tabular}

n.a., not analyzed.

a Outer sapwood.

b Inner heartwood.

c Sulfur-containing amino acid.

Table 4

Ultimate and elemental analysis of the fuels used

\begin{tabular}{lcccccccc}
\hline Fuel & Moisture $^{\mathrm{a}}$ & $\mathrm{Ash}^{\mathrm{a}}$ & $\mathrm{C}^{\mathrm{b}}$ & $\mathrm{H}^{\mathrm{b}}$ & $\mathrm{N}^{\mathrm{b}}$ & $\mathrm{S}^{\mathrm{b}}$ & $\mathrm{O}^{\mathrm{c}}$ & $\mathrm{O}^{\mathrm{N}}$ \\
\hline Bark & 9.0 & 3.0 & 55.0 & 6.2 & 0.4 & 0.03 & 38.4 & 95.0 \\
Shea & 12.0 & 5.3 & 52.4 & 5.4 & 2.9 & 0.28 & 39.0 & 13.6 \\
Pea & 9.3 & 2.4 & 46.3 & 6.6 & 4.3 & 0.16 & 42.6 & 9.9 \\
Soya & 7.4 & 4.6 & 54.5 & 7.6 & 6.8 & 0.36 & 30.7 & 4.5 \\
Whey & 7.4 & 3.8 & 53.1 & 7.1 & 15.3 & 1.29 & 23.2 & 1.5 \\
\hline
\end{tabular}

${ }^{\mathrm{a}}$ Weight $\%$ as received.

b Weight $\%$, dry ash-free basis.

c Weight $\%$ by difference, ash-free basis.

d Weight ratio.

proteins in bovine milk are whey proteins [24]. $\beta$ Lactoglobulin makes up $\approx 45 \%$ of the whey proteins and $\alpha$-lactalbumin an additional 20\%. These proteins contain 162 and 123 amino acid residues, respectively. The proteose-peptones make up $\approx 20 \%$ of the whey proteins and are large polypeptides rather than proteins [24]. The molar sulfur-to-nitrogen ratio for the amino acid composition of the whey (Table 3 ) is 0.035 , while the ratio calculated from the elemental composition (Table 4) is 0.037 . Consequently, all of the sulfur in the whey belongs to the protein fraction and not to the salt fraction. Soya beans and peas have low concentrations of sulfur-containing amino acids, which are reflected by their low S/N ratios. In wood, most of the sulfur exists in proteins [25].

The particles were pyrolyzed one at a time. The whey protein powder was compressed into a disk from which fragments were cut. The fragments' weight ranged from 117 to $174 \mathrm{mg}$ and they were all thinner than $1 \mathrm{~mm}$. The soya beans weighed 150 to $250 \mathrm{mg}$ and were $\approx 3-4 \mathrm{~mm}$ thick. The yellow peas were somewhat bigger, $240-270 \mathrm{mg}, 4-5 \mathrm{~mm}$ thick. Small pieces of bark (200-260 mg), with $\approx 4$ $\mathrm{mm}$ sides, were cut from bark pellets. Fragments of shea were cut from larger pieces to sizes of $\approx 3-5 \mathrm{~mm}$ (250-260 mg). Experiments with whey, bark, and soya beans were done at $700,800,900$, and $1000^{\circ} \mathrm{C}$. Experiments with shea and yellow peas were made at $900^{\circ} \mathrm{C}$. All experiments were made in triplicate runs.

\subsection{Experimental setup}

The fuels were pyrolyzed in a fluidized bed reactor (Fig. 3). The reactor is a cylindrical quartz glass reac- 


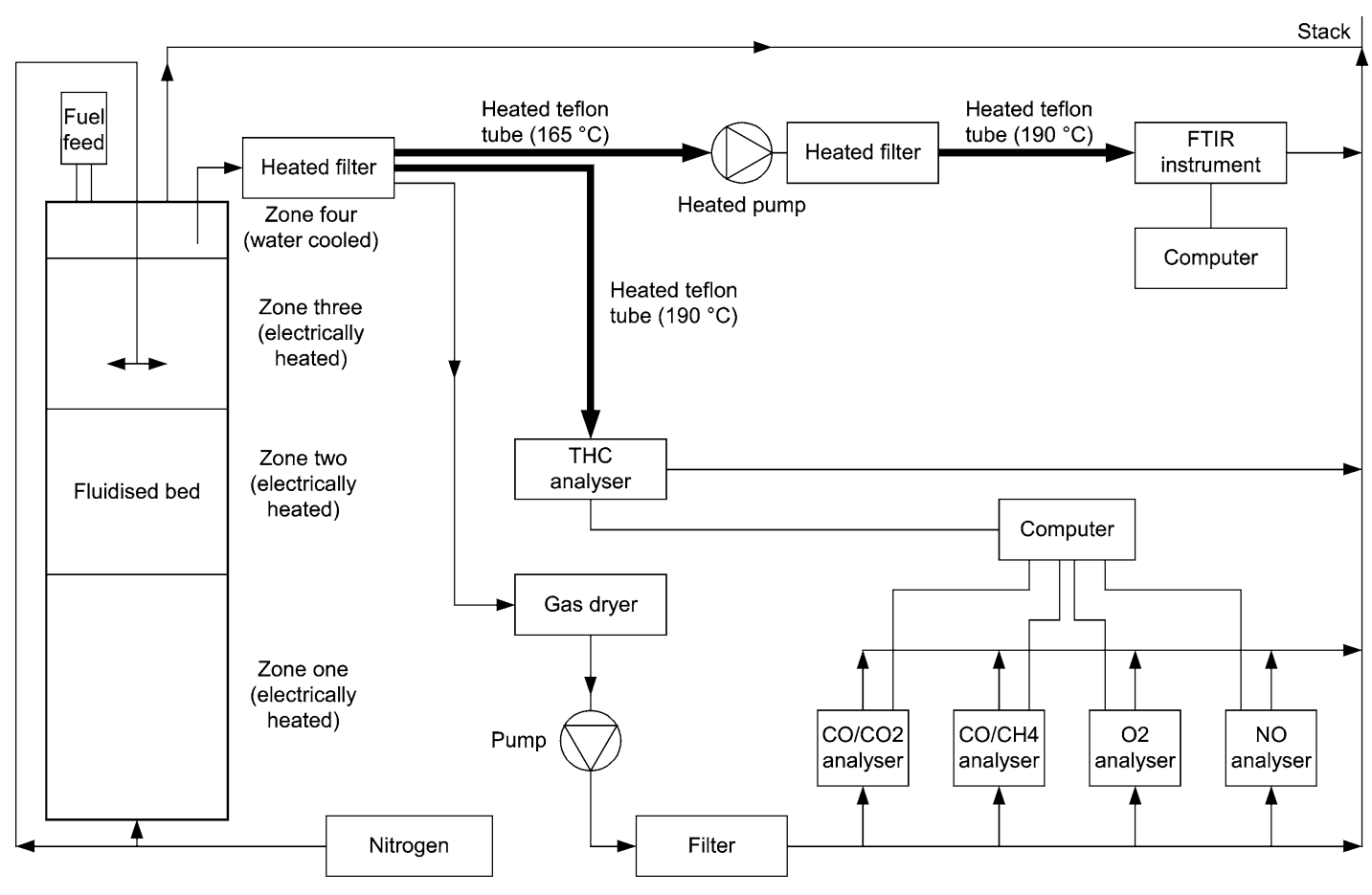

Fig. 3. The experimental setup.

tor (i.d. $60 \mathrm{~mm}$ ), placed in a vertical three-zone tube furnace, which is electrically heated. The temperature was separately controlled in each zone. Gas was introduced into the bottom of the reactor and heated in the first zone, $500 \mathrm{~mm}$ long. The quartz sand bed rested on a gas distribution plate that was located between the first and the second zone. The lengths of the second and third zones were $300 \mathrm{~mm}$ each. The bed material had sizes ranging between 250 and $315 \mu \mathrm{m}$ and the static height of the sand-bed was $\approx 60 \mathrm{~mm}$. The particles were fed from the top of the reactor through a small cylinder with two valves, one at the top and one at the bottom of the cylinder. This arrangement prevented air leakage and disturbances of the gas flow pattern within the reactor by always keeping one of the valves closed.

Experiments were made with nitrogen as the fluidizing gas. Nitrogen was also introduced some $300 \mathrm{~mm}$ from the top of the reactor. This second gas flow was intended to increase turbulence and gas mixing in the reactor. Gases left the reactor through holes in the reactor's top plate. Most of the gas from the reactor was removed as exhaust gas. However, pumps withdrew as much gas as the analysis instruments required. A filter placed on top of the reactor prevented fly ash, soot, and bed material from entering the analysis instruments. After the filter, the gas flow was divided into three streams: one leading to a FTIR (Fourier transform infrared) instru- ment (Bomem Model 9100), one leading to a FID (flame ionization detector) instrument (JUM Engineering Model 3-300A), and one leading to two NDIR (nondispersive infrared photometer) instruments (Rosemount Binos 100), a paramagnetic $\mathrm{O}_{2}$ analyzer (Leybold-Heraeus AG, Oxynos-1) and a chemiluminescence $\mathrm{NO}_{x}$ analyzer (ECO Physics). The concentrations of $\mathrm{CO}$ and $\mathrm{CO}_{2}$ were measured with one of the NDIR instruments, total hydrocarbons (THC) were analyzed with the FID. $\mathrm{CH}_{4}$ was measured with the second NDIR instrument. HCN, $\mathrm{NH}_{3}$, and HNCO were analyzed with the FTIR. The data acquisition times were $1 \mathrm{~s}$ for all instruments except the FTIR, which had a data acquisition time of $\approx 3$ s. In order to prevent $\mathrm{NH}_{3}$ from being catalytically destroyed at the metallic junction connecting the ceramic gas sampling probe in the reactor with the filter placed on top of the reactor top plate, or in the filter, the gases were cooled to $\approx 300-400{ }^{\circ} \mathrm{C}$ in a water-cooled fourth zone of the quartz glass reactor, $\approx 100 \mathrm{~mm}$ long, located between the third zone of the reactor and the reactor's top plate (Fig. 3).

\subsection{Quantification}

The concentrations of $\mathrm{NH}_{3}$ and $\mathrm{HCN}$ were determined from the $\approx 20-40$ FTIR spectra from each experiment, by spectral subtraction. No HNCO calibration spectra were available from the FTIR used in the experiments, but HNCO spectra from another 
FTIR, differing from the present FTIR only in gas cell volume and optical path length $(l)$, were available. Ideally, the absorbance $(A)$ at a specific wavenumber $(v)$ is linearly dependent on gas concentration $(c)$, according to Bouguer-Lambert-Beers law $(A=a l c)$ where $a$ is the absorptivity. The absorptivity is gasspecific and is a function of wavenumber. Ideally $a(v)$ from the second FTIR instrument could be used to quantify $\mathrm{HNCO}$ in the spectra from the present experiments. The functions $a(v)$ calculated from both FTIR instruments were compared for gases that absorb IR light in approximately the same spectral range as HNCO. The functions $a(v)$ for the two instruments were identical for both $\mathrm{CO}$ and $\mathrm{N}_{2} \mathrm{O}$, so it was assumed that the same should be true for HNCO. The absorbance at $2269.6 \mathrm{~cm}^{-1}$ was used as a measure of [HNCO]. $\mathrm{CO}_{2}$ also absorbs at that frequency, and therefore the interference with $\mathrm{CO}_{2}$ has to be taken into account. $\left[\mathrm{CO}_{2}\right]$ was measured at $2389.5 \mathrm{~cm}^{-1}$, and before [HNCO] was quantified at $2269.6 \mathrm{~cm}^{-1}$ the absorption caused by $\mathrm{CO}_{2}$ at that wavenumber was subtracted from the total absorbance. The absorbance was found to be linearly dependent on [HNCO] for the second FTIR, and the constant $a$ derived from this correlation was used to quantify [HNCO] from the experiments in this study. In practice the absorbance is often not linearly dependent on concentration. The nonlinearity is mainly an effect of insufficient resolution. Many of the gases calibrated in the FTIR show linear absorbance-concentration correlations at low absorbance, but at higher absorbance the correlations deviate from being linear. When this happens, the true concentrations are always higher than the calculated ones, if the linear correlations are used. Hence, there is a possibility that some of the [HNCO] derived from the experimental spectra are underestimates of the true values.

For transient events, it is known that measured $\left[\mathrm{NH}_{3}\right]$ are delayed in time, since ammonia adsorbs on the walls of gas sampling lines and other surfaces [26]. To avoid adsorbance of ammonia, the gas lines were heated to 165 and $190^{\circ} \mathrm{C}$, respectively (Fig. 3). The filters and the pump located between the reactor and the FTIR were also heated to prevent ammonia adsorption. The $\mathrm{NH}_{3}$ concentrations as a function of time look very different for whey, soya, and pea for concentrations down to $10 \mathrm{ppm}$. However, the concentration-time curves look the same for all of these fuels as soon as the concentrations have dropped to values lower than $10 \mathrm{ppm}$. This is probably an effect of the fact that, when the $\mathrm{NH}_{3}$ concentrations are high, the surfaces are saturated with adsorbed ammonia, which gradually desorbs when the flow of $\mathrm{NH}_{3}$ from the reactor ceases. The peak concentrations for all gases, except $\mathrm{NH}_{3}$, were found to coincide in time. For $\mathrm{NH}_{3}$ the peak concentration was slightly delayed compared to the other gases. The conclusion from this observation is that no gas other than $\mathrm{NH}_{3}$ adsorbs to any significant extent in the gas line. For experiments with bark at 700 and $800^{\circ} \mathrm{C}$, the concentrations of $\mathrm{HCN}$ were too low to allow quantification with high accuracy as in the other experiments. Although the concentrations of $\mathrm{NH}_{3}$ were quantified with higher accuracy than the $\mathrm{HCN}$ concentrations for bark at 700 and $800^{\circ} \mathrm{C}$, the accuracy was not high enough to be completely satisfactory in these experiments.

\section{Results}

$\mathrm{HCN}$ and $\mathrm{NH}_{3}$ were identified as pyrolysis products from all five fuels at all temperatures used in this study. HNCO could be identified in all spectra from whey, soya bean, and yellow pea. Because the $\mathrm{HNCO} / \mathrm{CO}_{2}$ ratio decreases with decreasing nitrogen content in the fuel, the HNCO signal became weaker and weaker in comparison to the $\mathrm{CO}_{2}$ and $\mathrm{CO}$ spectra. Consequently, identification of $\mathrm{HNCO}$ became more difficult for fuels with low nitrogen content. Fig. 4 illustrates how the $\mathrm{HNCO}$ spectra became more and more obscured by $\mathrm{CO}_{2}$ and $\mathrm{CO}$ as the fuel nitrogen content decreased. All the spectra in Fig. 4 were from experiments at $900{ }^{\circ} \mathrm{C}$ and with approximately the same $\mathrm{CO}_{2}$ concentrations. For shea, the $\mathrm{HNCO}$ spectrum did not appear until the spectra of $\mathrm{CO}_{2}$ and $\mathrm{CO}$ had been subtracted from the spectrum of the pyrolysate. This is probably the reason $\mathrm{HNCO}$ has not been observed in previous studies of wood pyrolysis in which FTIR has been used. In Fig. 5, a spectrum from an experiment with bark pellets at $900^{\circ} \mathrm{C}$ after subtraction of $\mathrm{CO}_{2}$ and $\mathrm{CO}$ is shown. It reveals a structure very close to that of $\mathrm{HNCO}$, but the signal is very low and is of the same height as the amplitude of the subtraction residual for $\mathrm{CO}_{2}$. Nevertheless, the signal indicates the presence of $\mathrm{HNCO}$ in the pyrolysis gases from bark. This is an expected result since all protein sources used so far, in this study as well as in the previous study with poly-L-leucine and poly-L-proline [6], did produce HNCO. The spectral residual for CO is large in Fig. 5, because the CO concentration was much higher than the concentration of the calibration spectrum used in the subtraction. The residual also reveals a structure in the range 2200 $2100 \mathrm{~cm}^{-1}$; this is not an effect of poor subtraction but comes from the presence of another species. The presence of this other species is more apparent at lower pyrolysis temperatures. Fig. 6 shows a spectrum of pyrolysate from bark at $700{ }^{\circ} \mathrm{C}$ and the same spectrum after subtraction of $\mathrm{CO}$ and $\mathrm{CO}_{2}$. A strong signal remains in the range $2200-2100 \mathrm{~cm}^{-1}$. This species is probably ketene, $\mathrm{CH}_{2} \mathrm{CO}$, which is known to absorb IR light in that region [27]. Especially the peak at the band center at $2150 \mathrm{~cm}^{-1}$ is typical for ketene. 

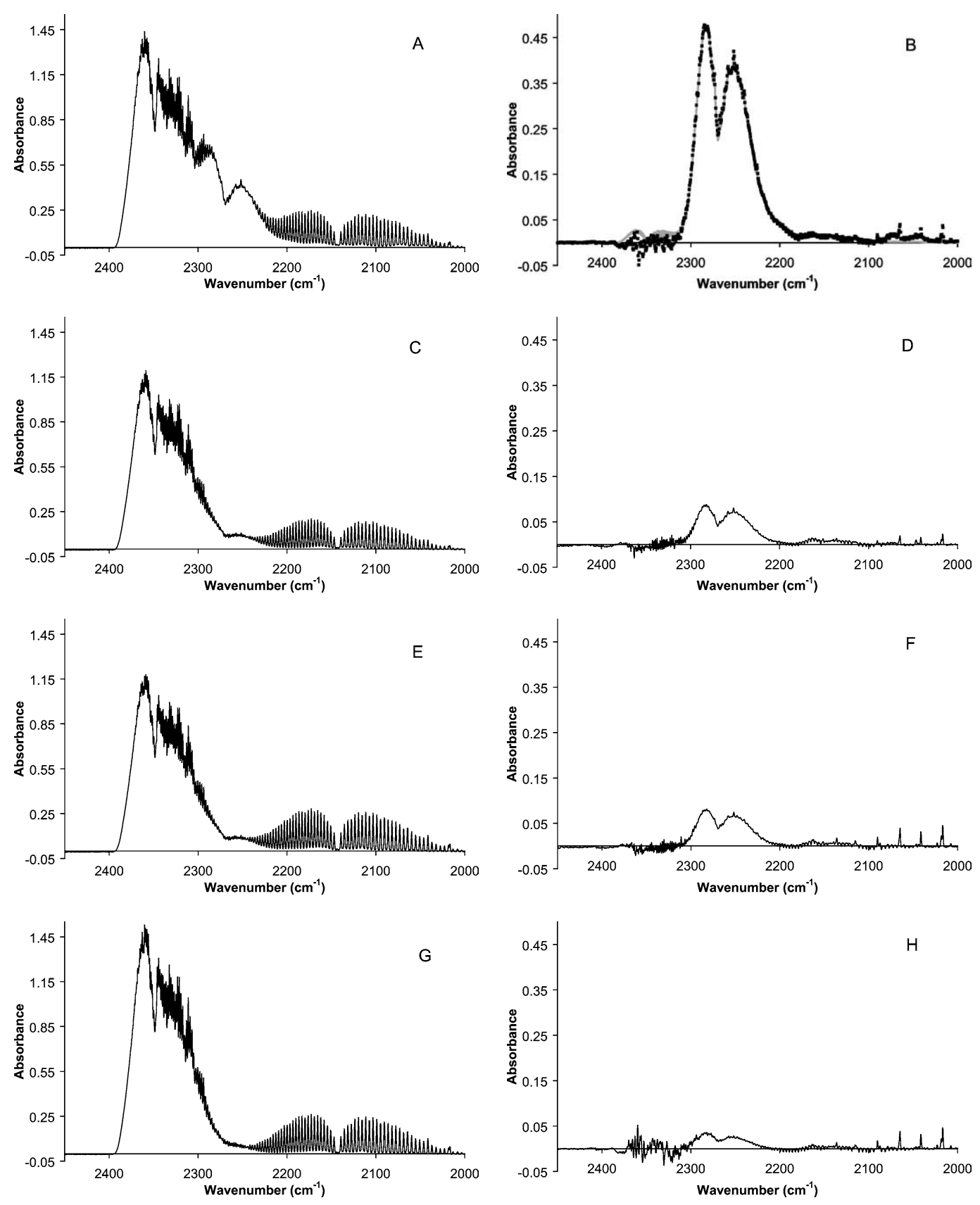

Fig. 4. Examples of spectra from pyrolysis experiments at $900^{\circ} \mathrm{C}$ for (A) whey, (C) soya bean, (E) yellow pea, and (G) shea. Also depicted are the same spectra after spectral subtraction of $\mathrm{CO}_{2}$ and $\mathrm{CO}$ for (B) whey (black dotted line), (D) soya bean, (F) yellow pea, and $(\mathrm{H})$ shea. In (B), the calibration spectrum of $1247 \mathrm{ppm}$ HNCO from the second FTIR, multiplied by 1.52, is also shown (thick gray line).

The presence of $\mathrm{HNCO}$ from bark is also more apparent in the spectrum taken at $700^{\circ} \mathrm{C}$ (Fig. 6) than in that at $900{ }^{\circ} \mathrm{C}$ (Fig. 5).

$\mathrm{HNCO}$ was quantified for all the experiments with whey, soya beans, and peas (note that the quantifica- tion method may give underestimates of the concentrations). The $\mathrm{HNCO} / \mathrm{HCN}$ ratios were found to decrease with increasing temperature for both whey and soya beans (Fig. 7). Whey has a higher $\mathrm{HNCO} / \mathrm{HCN}$ ratio than soya beans at all temperatures used in this 

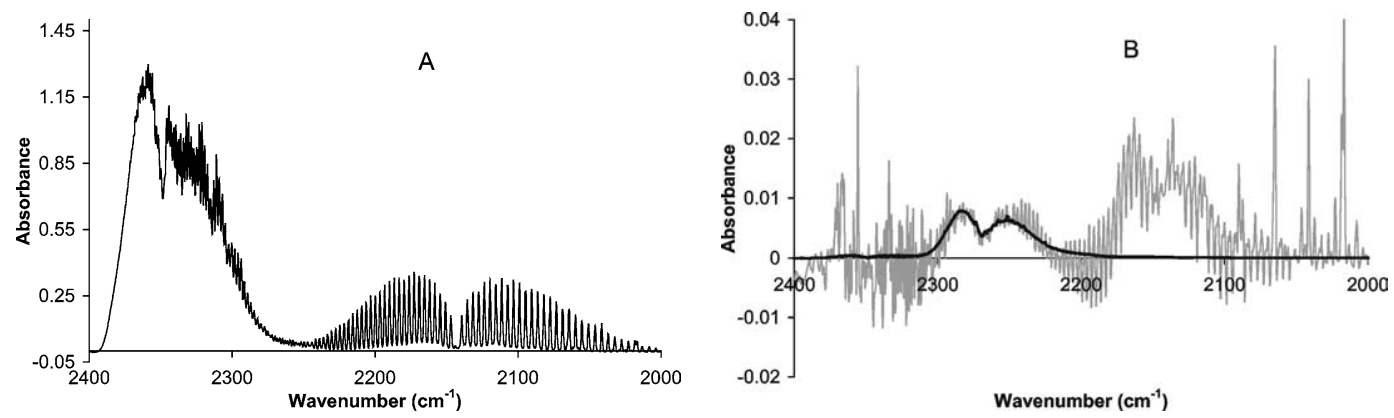

Fig. 5. (A) An example of spectra from pyrolysis of bark at $900{ }^{\circ} \mathrm{C}$ and (B) the residue after spectral subtraction of $\mathrm{CO}$ and $\mathrm{CO}_{2}$ (gray line) and the spectrum of 1247 ppm HNCO from the second FTIR, multiplied by 0.025 (thick black line).
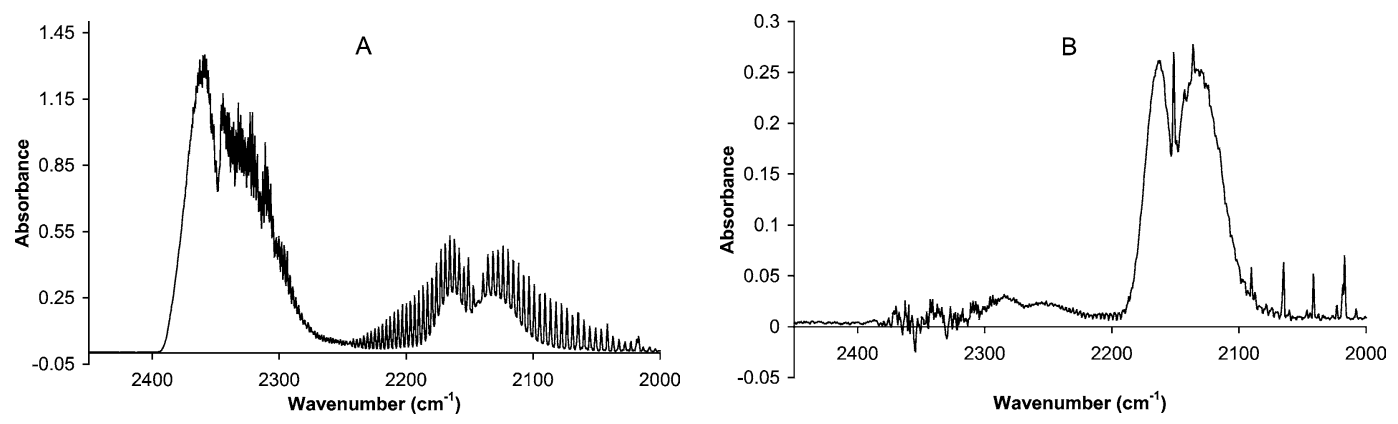

Fig. 6. (A) An example of spectra from pyrolysis of bark at $700{ }^{\circ} \mathrm{C}$ and (B) the residue after spectral subtraction of $\mathrm{CO}$ and $\mathrm{CO}_{2}$.

study. For peas pyrolyzed at $900^{\circ} \mathrm{C}$, the $\mathrm{HNCO} / \mathrm{HCN}$ ratio is the same as for soya beans pyrolyzed at $900{ }^{\circ} \mathrm{C}$ (Fig. 7).

The $\mathrm{HCN} / \mathrm{NH}_{3}$ ratio has a significant temperature dependence for all materials studied (Fig. 8). Whey has a higher $\mathrm{HCN} / \mathrm{NH}_{3}$ ratio than soya beans and bark at all temperatures. The $\mathrm{HCN} / \mathrm{NH}_{3}$ ratio could not be measured with any accuracy at 700 and $800^{\circ} \mathrm{C}$ for bark due to low concentrations of HCN. At 900 and $1000^{\circ} \mathrm{C}$, the concentrations of $\mathrm{HCN}$ were higher, which made quantification more reliable. In this temperature range the $\mathrm{HCN} / \mathrm{NH}_{3}$ ratio decreased with decreasing temperature. It was also established that the $\mathrm{HCN} / \mathrm{NH}_{3}$ ratio continued to decrease with decreasing temperature for bark also in the temperature range in which exact quantification of $\mathrm{HCN}$ was not possible. In fact, the temperature dependence of the $\mathrm{HCN} / \mathrm{NH}_{3}$ ratio for bark is the same as for whey and soya beans (Fig. 8). At each temperature at which the ratio could be estimated with any accuracy, the $\mathrm{HCN} / \mathrm{NH}_{3}$ ratio for bark was slightly higher than for soya beans and lower than for whey. The $\mathrm{HCN} / \mathrm{NH}_{3}$ ratio for shea pyrolyzed at $900{ }^{\circ} \mathrm{C}$ was lower than for any of the other fuels at this temperature, while the ratio for yellow peas was approximately the same as for bark and soya beans (Fig. 8). The small size of the whey particles makes the experiments with whey almost isothermal. For the other fuels, the size of the

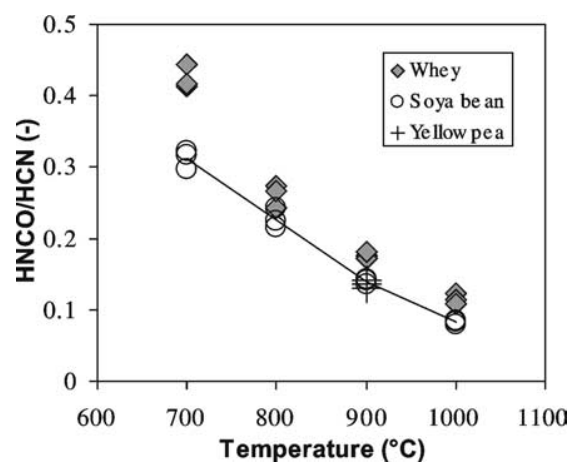

Fig. 7. Molar ratios of HNCO and HCN yields for whey protein, soya beans, and yellow peas. Trend line for soya beans.

particles leads to a slower heating of the particles' interior. Consequently, a larger part of the pyrolysis for these fuels will proceed at temperatures below that of the reactor. This is probably the reason whey protein has a higher $\mathrm{HCN} / \mathrm{NH}_{3}$ ratio than any of the other fuels (Fig. 8).

The $\mathrm{O}_{2}$ instrument confirmed that the reactor was free from oxygen in every experiment. However, some oxidation of the volatile nitrogenous species can occur, since the pyrolysis gases contain high concentrations of oxygen-containing species, particularly $\mathrm{H}_{2} \mathrm{O}$ and $\mathrm{CO}_{2}$. The $\mathrm{NO}$ concentrations were low in every experiment. The yields of NO increased with 


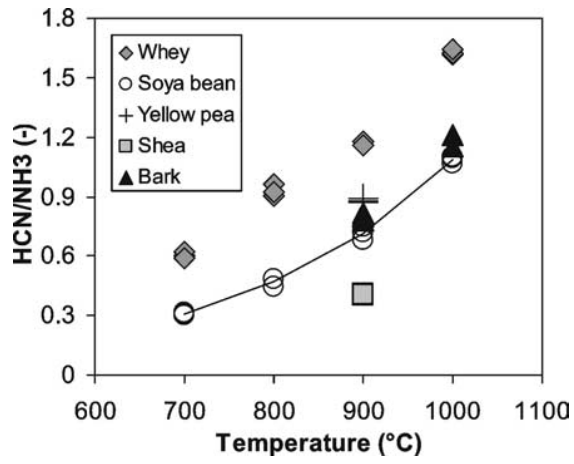

Fig. 8. Molar ratios of $\mathrm{HCN}$ and $\mathrm{NH}_{3}$ yields for whey protein, soya beans, yellow peas, shea, and bark. Trend line for soya beans.

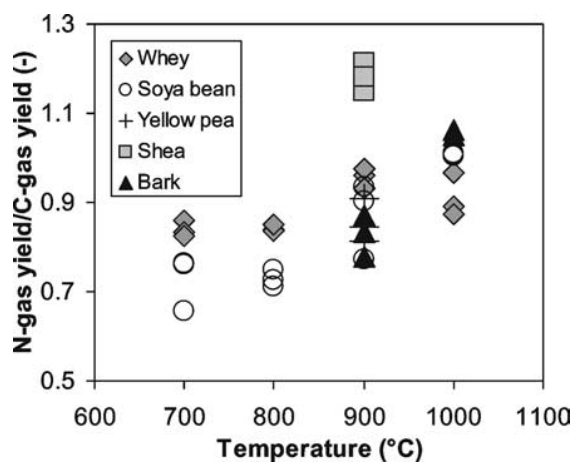

Fig. 9. The ratio between volatile nitrogen and volatile carbon normalized to the fuel N/C ratio as a function of reactor temperature for whey protein, soya beans, yellow peas, shea, and bark.

decreasing nitrogen content of the fuel. For bark, as much as $2.5 \%$ of the volatile nitrogen was identified as NO, while the NO never exceeded $0.3 \%$ of the volatile nitrogen for whey.

Usually the nitrogen concentration is more enriched in the char than is the carbon concentration when wood is pyrolyzed, and this trend is generally validated in this work. A higher portion of the fuel carbon than the fuel nitrogen was found in the gas phase after pyrolysis, especially at low temperatures (Fig. 9). The carbon in the gas phase is the sum of $\mathrm{CO}, \mathrm{CO}_{2}$, THC, and $\mathrm{HNCO}$, and the nitrogen in the gas phase is the sum of $\mathrm{HCN}, \mathrm{NH}_{3}, \mathrm{HNCO}$, and $\mathrm{NO}$ for whey, soya bean, and pea. For bark and shea, the carbon in the gas phase is the sum of $\mathrm{CO}, \mathrm{CO}_{2}$, and THC, and the nitrogen in the gas phase is the sum of $\mathrm{HCN}, \mathrm{NH}_{3}$, and $\mathrm{NO}$. A trend noticed for the experiments at $900{ }^{\circ} \mathrm{C}$ was that the higher the yield of volatile nitrogen, the higher the ratio of $\mathrm{HCN}$ to $\mathrm{NH}_{3}$.

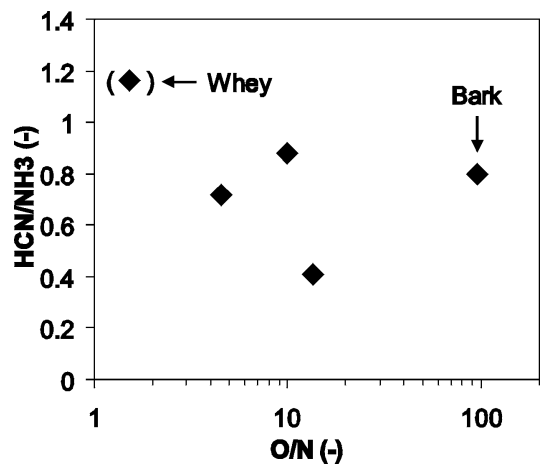

Fig. 10. Molar $\mathrm{HCN} / \mathrm{NH}_{3}$ ratio in pyrolysate as a function of the fuel original weight $\mathrm{O} / \mathrm{N}$ ratio (see Table 4; note the logarithmic scale). Reactor temperature: $900{ }^{\circ} \mathrm{C}$.

\section{Discussion}

The $\mathrm{HCN} / \mathrm{NH}_{3}$ ratio under pyrolysis conditions was found to be a function of the fuel's $\mathrm{O} / \mathrm{N}$ ratio in a study involving the bark from three different kinds of wood, four kinds of peat, one German brown coal, and one Colombian bituminous coal [8]. In a followup study with different model compounds of pyridine type, pyrrole type, and amino type, no such correlation could be found [28]. Neither could the results in this study establish any correlation between the $\mathrm{HCN} / \mathrm{NH}_{3}$ ratio and the $\mathrm{O} / \mathrm{N}$ ratio of the model compounds and bark, at least if the whey particles were excluded (Fig. 10). The whey particles were much smaller than the other particles and would therefore experience higher heating rates and consequently have a higher $\mathrm{HCN} / \mathrm{NH}_{3}$ ratio than the other compounds. The reason the $\mathrm{HCN} / \mathrm{NH}_{3}$ ratio is not significantly correlated with the fuel's $\mathrm{O} / \mathrm{N}$ ratio is probably that the secondary gas-phase reactions in which $\mathrm{HCN}$ is converted into $\mathrm{NH}_{3}$ are of less importance than suggested. Instead, the fuel-nitrogen functionality dictates the $\mathrm{HCN} / \mathrm{NH}_{3}$ split. In this study, proteins are the main nitrogen functionalities in every fuel, and though the amino acid composition may vary between the fuels used, the variations in amino acid composition between natural proteins are normally not too profound, and therefore the $\mathrm{HCN} / \mathrm{NH}_{3}$ ratio is not greatly affected by this. In the previous study [8], in which the correlation between $\mathrm{HCN} / \mathrm{NH}_{3}$ ratio and fuel $\mathrm{O} / \mathrm{N}$ ratio was established, the fuel $\mathrm{O} / \mathrm{N}$ ratio was thought not to have any strong correlation with fuel $\mathrm{N}$ functionality. However, biomass has mainly protein nitrogen (believed to be pyrrolic nitrogen in [8]), and peat has high proportions of fuel nitrogen in protein and amino functionalities [29]. Consequently, these fuels produce high yields of ammonia. For coals, the form of volatile nitrogen depends on the nitrogen functionalities in the coal. The nitrogen in pyrrolic 
and pyridinic forms releases $\mathrm{HCN}$, amine/quaternary nitrogen releases $\mathrm{NH}_{3}$ [30], and pyridone nitrogen releases $\mathrm{HCN}$ and $\mathrm{HNCO}$ [21]. The coal's $\mathrm{O} / \mathrm{N}$ ratio is usually correlated with the rank of the coal, which in turn is correlated with the nitrogen functionality. From an XANES study [31], the pyridone fraction (producing $\mathrm{HNCO}$, usually mistaken for $\mathrm{NH}_{3}$ when wet methods are used to analyze $\mathrm{NH}_{3}$ as in [8]) of the coal nitrogen was found to increase with the fuel's oxygen concentration as with the fuel's $\mathrm{O} / \mathrm{N}$ ratio [31]. The amine fraction did not correlate with the $\mathrm{O} / \mathrm{N}$ ratio in that study [31]. However, in an XPS study [30], the coal $\mathrm{O} / \mathrm{N}$ ratio was found to correlate with the quaternary fraction of the fuel nitrogen. From a compilation of XPS data it was found that the fraction of quaternary nitrogen decreases with increasing rank for coals with a carbon concentration below $75 \%$, while for coals with higher carbon concentrations, this correlation is weak [21]. Hence, the formation of $\mathrm{HCN}, \mathrm{NH}_{3}$, and $\mathrm{HNCO}$ seems to be correlated with the fuel nitrogen functionality. Lowrank coals have larger fractions of coal nitrogen in amine/quaternary and pyridone structures and thus produce higher yields of $\mathrm{NH}_{3}$ and $\mathrm{HNCO}$ than highrank coals. For coals, one would therefore expect the $\mathrm{HCN} / \mathrm{NH}_{3}$ ratio, and particularly the $\mathrm{HCN} /(\mathrm{HNCO}+$ $\mathrm{NH}_{3}$ ) ratio (which is what was actually measured in [8]), to increase with increasing rank, not because of different secondary gas-phase reactions, but because of differences in nitrogen functionality.

The $\mathrm{HNCO} / \mathrm{HCN}$ ratio decreases with increasing reactor temperature (Fig. 7). This is in accordance with the idea that $\mathrm{HNCO}$ and $\mathrm{HCN}$ are mainly formed from cracking of cyclic amides and that the selectivity toward formation of $\mathrm{HCN}$ over the formation of $\mathrm{HNCO}$ for cyclic amides is increased with increasing temperature [6].

The $\mathrm{HCN} / \mathrm{NH}_{3}$ ratio increases with increasing reactor temperature (Fig. 8). The formation of $\mathrm{NH}_{3}$ is suggested to take place mainly in the solid phase in reactions that simultaneously form char. This hypothesis is in line with the results for the polyamide nylon 6,6 [19]: when pyrolyzed at $800{ }^{\circ} \mathrm{C}$, the $\mathrm{HCN}$ yield increased by a factor of 7 when the gas residence time was increased from 0.33 to $1.70 \mathrm{~s}$. However, the $\mathrm{NH}_{3}$ yield was independent of the gas residence time in the investigated range. At $1000^{\circ} \mathrm{C}$, more $\mathrm{HCN}$ and less $\mathrm{NH}_{3}$ were formed than at $800^{\circ} \mathrm{C}$ [19]. This implies that $\mathrm{HCN}$ and $\mathrm{NH}_{3}$ are formed through competing reactions. Since the formation of $\mathrm{HCN}$ depended on gas residence time at $800^{\circ} \mathrm{C}$, while the $\mathrm{NH}_{3}$ formation did not, one can conclude that the competition between $\mathrm{NH}_{3}$ and $\mathrm{HCN}$ is not taking place in the gas phase for nylon 6,6. The HCN must mainly come from gas-phase cracking of larger fragments. $\mathrm{NH}_{3}$ can be formed either directly from the solid mater- ial or from species that do not produce HCN when cracked, but produce mainly $\mathrm{NH}_{3}$. In the latter case, the gas-phase cracking must be much faster than the cracking of tar species that leads to HCN. In either case, the competition between the formation of $\mathrm{HCN}$ and that of $\mathrm{NH}_{3}$ seems to take place in the solid phase.

The hypothesis that $\mathrm{NH}_{3}$ is mainly formed in the solid phase in reactions that simultaneously lead to char formation, in competition with the formation of cyclic amides, could also explain why the poly-Lleucine and poly-L-proline used previously produced $\mathrm{HCN} / \mathrm{NH}_{3}$ ratios so much higher [6] than any of the proteins in this study, since neither poly-L-leucine nor poly-L-proline produced any char [6], which all of the proteins used in this study did. Of the fuels used in this study, the smallest particles showed the highest $\mathrm{HCN} / \mathrm{NH}_{3}$ ratios at all temperatures, which most probably is an effect of the fact that the average temperature in the particles' interior is higher for smaller particles than for larger particles. The $\mathrm{HNCO} / \mathrm{HCN}$ ratio deviates less than the $\mathrm{HCN} / \mathrm{NH}_{3}$ ratio for whey particles compared to the other fuels, and this is probably because the split between $\mathrm{HNCO}$ and $\mathrm{HCN}$ mainly takes place in the gas phase. Of the four fuels with comparable particle sizes, and therefore with similar heating rates, the yield of volatile nitrogen at $900^{\circ} \mathrm{C}$ was positively correlated with the $\mathrm{HCN} / \mathrm{NH}_{3}$ ratio, which favors the idea that the formations of $\mathrm{NH}_{3}$ and char nitrogen are linked.

\section{Conclusions}

The distribution of nitrogenous species in the pyrolysate of model substances and bark does not depend significantly on the $\mathrm{O} / \mathrm{N}$ ratio, but rather on the fuel's nitrogen functionalities. For biomass, most of the nitrogen is in the form of proteins, and proteins are therefore the most suitable model compounds for nitrogen in biomass. Pyrolysis of biomass fuels produces $\mathrm{HCN}, \mathrm{NH}_{3}$, and $\mathrm{HNCO}$. For bark and shea, HNCO could be observed but not quantified. However, the use of model compounds gives reliable estimates of how much HNCO is formed at different temperatures. Experiments with whey, soya beans, and yellow peas revealed that the $\mathrm{HNCO} / \mathrm{HCN}$ ratio is only slightly dependent on the kind of model substance. However, the temperature dependence of the $\mathrm{HNCO} / \mathrm{HCN}$ ratio is strong. The ratio decreases with increasing temperature. At low temperatures, a high portion of the nitrogen is retained in the char, and ammonia is the main gaseous nitrogenous species. At high temperatures, more nitrogen is released and $\mathrm{HCN}$ is the main nitrogen-containing species. Two main reaction routes for protein nitrogen are suggested: one leading to $\mathrm{NH}_{3}$ and char nitrogen and the 
other leading to volatile cyclic amides. Cracking of the cyclic amides is suggested to be the main reaction leading to $\mathrm{HCN}$ and $\mathrm{HNCO}$. Since the experiments were performed in an inert atmosphere, low yields of $\mathrm{NO}$ were observed and no $\mathrm{N}_{2} \mathrm{O}$ was found.

\section{Acknowledgments}

This work was financed by the Swedish Energy Administration and by the Center for Combustion Science and Technology in Sweden (CECOST).

\section{References}

[1] P. Kilpinen, M. Hupa, Combust. Flame 85 (1991) 94104.

[2] T. Hulgaard, P. Glarborg, K. Dam-Johansen, in: E. Anthony (Ed.), 11th International Conference on Fluidized Bed Combustion, The American Society of Mechanical Engineers, New York, 1991, pp. 991-998.

[3] V.J. Wargadalam, G. Löffler, F. Winter, H. Hofbauer, Combust. Flame 120 (2000) 465-478.

[4] K. Persson, in: European Workshop on the Emission of Nitrous Oxide, Lisbon, June 6-8, 1990.

[5] M. Kleemann, M. Elsener, M. Koebel, A. Wokaun, Ind. Eng. Chem. Res. 39 (2000) 4120-4126.

[6] K.-M. Hansson, L.-E. Åmand, A. Habermann, F. Winter, Fuel 82 (2003) 653-660.

[7] K.-M. Hansson, Principles of Biomass Pyrolysis with Emphasis on the Formation of the Nitrogen-Containing Gases $\mathrm{HNCO}, \mathrm{HCN}$ and $\mathrm{NH}_{3}$, Ph.D. thesis, Chalmers University of Technology, Göteborg, Sweden, 2003.

[8] M.J. Aho, J.P. Hämäläinen, J.L. Tummavuori, Combust. Flame 95 (1993) 22-30.

[9] J. Leppälahti, Fuel 74 (1995) 1363-1368.

[10] J.J. Saastamoinen, J.P. Hämäläinen, P. Kilpinen, in: Proceedings of the 4th International Conference on Technology and Combustion for a Clean Environment, Lisbon, July 7-10, 1997.

[11] J.J. Sauter, S. Wellenkamp, Holzforschung 52 (1998) 255-262.

[12] S. Wetzel, C. Demmers, J.S. Greenwood, Planta 178 (1989) 275-281.

[13] K. Matsuoka, T. Horii, T. Aihara, T. Kyotani, A. Tomita, Energy Fuels 17 (2003) 359-362.

[14] K. Matsuoka, T. Horii, P. Chambrion, T. Kyotani, A. Tomita, Carbon 38 (2000) 775-785.

[15] K.J. Voorhees, W. Zhang, A.D. Hendricker, B. Murugaverl, J. Anal. Appl. Pyrol. 30 (1994) 1-16.

[16] T.O. Munson, J. Vick, J. Anal. Appl. Pyrol. 8 (1985) 493-501.

[17] M. Garcìa-Pèrez, A. Chaala, C. Roy, J. Anal. Appl. Pyrol. 65 (2002) 111-136.

[18] R.S. Lehrle, I.W. Parsons, M. Rollinson, Polym. Degrad. Stab. 67 (2000) 21-33.

[19] J.-N. Leichtnam, D. Schwartz, R. Gadiou, J. Anal. Appl. Pyrol. 55 (2000) 255-268.
[20] C.C. Lim, Z.P. Xu, H.H. Huang, C.Y. Mok, W.S. Chin, Chem. Phys. Lett. 325 (2000) 433-439.

[21] K.-M. Hansson, J. Samuelsson, L.-E. Åmand, C. Tullin, Fuel 82 (2003) 2163-2172.

[22] L.L. Tan, C.-Z. Li, Fuel 79 (2000) 1883-1889.

[23] E.B. Ledesma, C.-Z. Li, P.F. Nelson, J.C. Mackie, Energy Fuels 12 (1998) 536-541.

[24] H. Swaisgood, in: O. Fennema (Ed.), Food Chemistry, third ed., Marcel Dekker, New York, 1996, pp. 841-878.

[25] W.L. Banwart, J.M. Bremner, Soil Biol. Biochem. 8 (1976) 439-443.

[26] H. Kassman, L.-E. Åmand, B. Leckner, J. Inst. Energy 70 (1997) 95-101.

[27] G.R. Allen, N.D. Renner, D.K. Russell, Chem. Commun. (1998) 703-704.

[28] J.P. Hämäläinen, M.J. Aho, J.L. Tummavuori, Fuel 73 (1994) 1894-1898.

[29] P.H. Given, C.H. Dickinson, in: E.A. Paul, A.D. McLaren (Eds.), Soil Biochemistry, vol. 3, Marcel Dekker, New York, 1975, pp. 123-212.

[30] S. Kambara, T. Takarada, Y. Yamamoto, K. Kato, Energy Fuels 7 (1993) 1013-1020.

[31] O.C. Mullins, S. Mitra-Kirtley, J. van Elp, S.P. Cramer, Appl. Spectrosc. 47 (1993) 1268-1275.

[32] M. Predel, W. Kaminsky, Bioresour. Technol. 66 (1998) 113-117.

[33] M. Saenger, E.-U. Hartge, J. Werther, T. Ogada, Z. Siagi, Renewable Energy 23 (2001) 103-121.

[34] N. Özbay, A.E. Pütün, B.B. Uzun, E. Pütün, Renewable Energy 24 (2001) 615-625.

[35] A.E. Pütün, H.F. Gerçel, Ö.M. Koçkar, Ö. Ege, C.E. Snape, E. Pütün, Fuel 75 (1996) 1307-1312.

[36] A.E. Pütün, A. Özcan, H.F. Gerçel, E. Pütün, Fuel 80 (2001) 1371-1378.

[37] M.N. Islam, R. Zailani, F.N. Ani, Renewable Energy 17 (1999) 73-84.

[38] S. Vitolo, L. Petarca, B. Bresci, Bioresour. Technol. 67 (1999) 129-137.

[39] J.M. Encinar, F.J. Beltrán, A. Bernalte, A. Ramiro, J.F. González, Biomass Bioenergy 11 (1996) 397-409.

[40] R. Zanzi, K. Sjöström, E. Björnbom, Biomass Bioenergy 23 (2002) 357-366.

[41] S. Şensöz, D. Angin, S. Yorgun, Biomass Bioenergy 19 (2000) 271-279.

[42] Ö. Onay, S.H. Beis, Ö.M. Koçkar, J. Anal. Appl. Pyrol. 58-59 (2001) 995-1007.

[43] F. Karaosmanoğlu, E. Tetik, E. Göllü, Fuel Process. Technol. 59 (1999) 1-12.

[44] F. Karaosmanoğlu, A. Işigigür-Ergüdenler, A. Sever, Energy Fuels 14 (2000) 336-339.

[45] S.H. Beis, Ö. Onay, Ö.M. Koçkar, Renewable Energy 26 (2002) 21-32.

[46] H.F. Gerçel, Biomass Bioenergy 23 (2002) 307-314.

[47] H.F. Gerçel, Bioresour. Technol. 85 (2002) 113-117.

[48] S. Yorgun, S. Şensöz, Ö.M. Koçkar, J. Anal. Appl. Pyrol. 60 (2001) 1-12.

[49] F.A. Agblevor, S. Besler-Guran, D. Montane, A.E. Wiselogel, in: A.V. Bridgwater, D.G.B. Boocock (Eds.), Developments in Thermochemical Biomass Conversion, IEA Bioenergy, Blackie Academic \& Professional, London, 1997, pp. 741-755. 
[50] M.E. Boucher, A. Chaala, C. Roy, Biomass Bioenergy 19 (2000) 337-350.

[51] S. Chebil, A. Chaala, C. Roy, Fuel 79 (2000) 671-683.

[52] F. Winter, C. Wartha, G. Löffler, H. Hofbauer, Proc. Combust. Inst. 26 (1996) 3325-3334.
[53] H. Thunman, F. Niklasson, F. Johnsson, B. Leckner, Energy Fuels 15 (2001) 1488-1497.

[54] R.A. Laidlaw, G.A. Smith, Holzforschung 19 (1965) 129-134.

[55] V.U. Adelsberger, H.-J. Petrowitz, Holzforschung 30 (1976) 109-113, in German. 